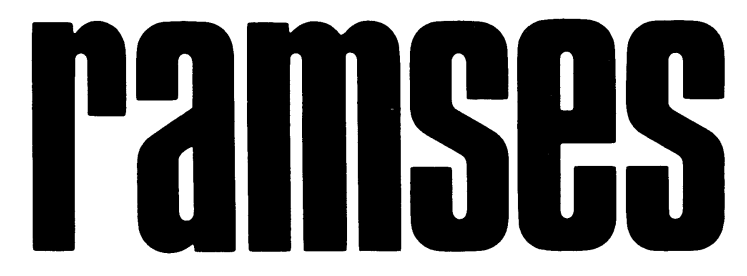

Rapport Annuel Mondial sur le Système Economique et les Stratégies

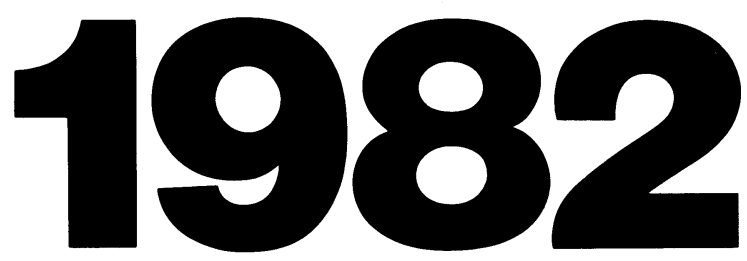


This report has been prepared by a team working at IFRI under the direction of Albert BRESSAND and drawing on contributions and background studies from outside consultants. Dr. BRESSAND takes full and sole responsibility for the final version of the text presented in this report.

\title{
IFRI team
}

\author{
Albert BRESSAND \\ Catherine DISTLER - Pierre JACQUET \\ Valerie de BELLOY - Christian CHARPY - Jean KLEIN \\ Ali BOUTALEB - Daniel LIPPERA - Pierre FERNANDEZ \\ Bibliography, chronology \\ Marie-Claude de SAINT-HILAIRE - Elisabeth KOSELLEK \\ Editorial assistance \\ Patricia BESSON - Marie-Ange PAMARD - Marielle CORTYL
}

\section{James K. GALBRAITH \\ Thane GUSTAFSON \\ Olivier GAUSSOT \\ Michel DEVELLE \\ Dan DIMANCESCU \\ Eugène BERG}

\section{With scientific contributions from}

Charles GOLDFINGER
Kevin LEWIS
Nicholas LETHBRIDGE
Michel LELART
Jean LEMPERIERE
Lionel BORDARIER

Ghassane SALAME Michel TATU

Christophe RIBOUD Jacques LOUP

Laurent de MAUTORT Jean Claude BERTHELEMY

Special thanks are also due to Pierre HASSNER, Centre d'Etudes et de Recherches Internationales (CERI, Fondation Nationale des Sciences Politiques), for his contribution to Chapter 1.

The English translation has been prepared by Derek BAIN, Malcom LIVESEY, and Joyce SCHONFIELD, under the direction of Francis WELLS.

We want to thank all those who have agreed to take part, without of course being in any way responsible for the views expressed here, in the seminars and working sessions organized for the preparation of this report:

Abdelkader SID-AHMED

C. Fred BERGSTEN

Robert CASSEN

Richard COOPER

Yves FRANCHET

William HOGAN

Edward KRAPELS

Eric MELBY

Marc PERRIN deBRICHAMBAUT

Georges SOKOLOFF

Gerard WILD
Alvin ALM

Yves BERTHELOT

Bernard CAZES

Pierre DESPRAIRIES

Jean-Louis GERGORIN John HOLDREN

Paul MENTRE de LOYE

Bernard POLGE deCOMBRET

Joseph STANISLAW John ZYSMAN
Ezio ANDRETA Albert CARNESALE Benjamin COHEN François DIDIER

Pierre HAAS

Peter KENEN Henry LEE Joseph NYE

Barney RUSH

Christian STOFFAES

\section{Graphics}

Catherine LE GUYON - Patrick BOUDAULT

The research program on which this report is based has been financed in part through a grant from the German Marshall Fund of the United States.

\section{Director of publication}

Thierry de MONTBRIAL, Director of IFRI 


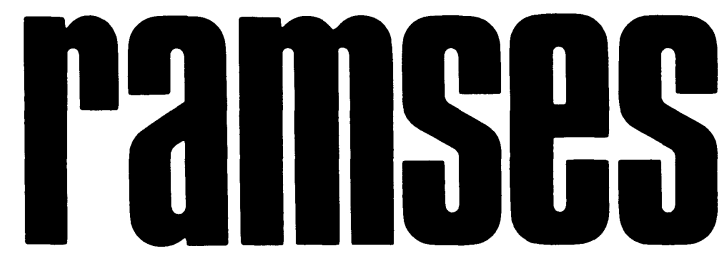

Annual Report by the French Institute for International Relations

\title{
The State of the World Economy
}

\author{
ifri \\ Project director: Albert BRESSAND \\ Foreword by Joseph S. NYE \\ Preface by Thierry de MONTBRIAL
}


Copyright (C) 1982 by Institut Français des Relations Internationales. All rights reserved. No part of this publication may be reproduced, stored in a retrieval system, or transmitted in any form or by any means, electronic, mechanical, photocopy, recording, or otherwise without the prior written consent of the publisher.

\section{Softcover reprint hardcover of the 1st edition 1982}

First published 1982 by

THE MACMILLAN PRESS LTD

London and Basingstoke

Associated Companies throughout the world

ISBN 978-1-349-06694-0 ISBN 978-1-349-06692-6 (eBook)

DOI 10.1007/978-1-349-06692-6 


\section{CONTENTS}

List of Illustrations $\ldots \ldots \ldots \ldots \ldots \ldots \ldots \ldots \ldots \ldots \ldots \ldots \ldots \ldots \ldots \ldots \ldots \ldots \ldots$

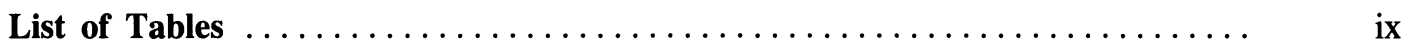

Foreword By Joseph S. Nye $\ldots \ldots \ldots \ldots \ldots \ldots \ldots \ldots \ldots \ldots \ldots \ldots \ldots \ldots \ldots \ldots \ldots \ldots \ldots \ldots$

Preface by Thierry de Montbrial $\ldots \ldots \ldots \ldots \ldots \ldots \ldots \ldots \ldots \ldots \ldots \ldots \ldots \ldots \ldots$

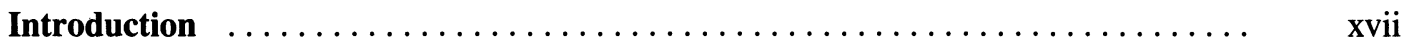

PART ONE:

ARMS AND ENERGY: A EUROPEAN PERSPECTIVE $\ldots \ldots \ldots \ldots \ldots \ldots \ldots$.

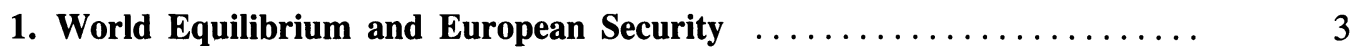

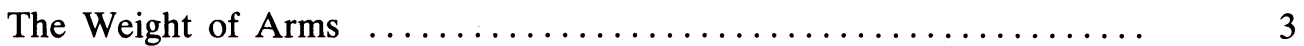

Arms Buildups Around the World $\ldots \ldots \ldots \ldots \ldots \ldots \ldots \ldots \ldots \ldots \ldots \ldots$

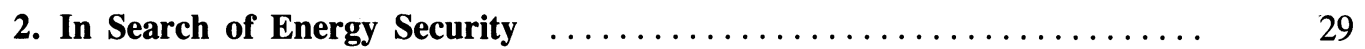

From Oil Shock to Oil Glut: the Persistent Vulnerabilities .......... 30

The Energy Policy According to Reagan .................. 42

Long-Term Energy Security: The Limits of the Market Approach .... 50

The Short-Term Dimension of Energy Security $\ldots \ldots \ldots \ldots \ldots \ldots \ldots . \ldots 2$

For Collective Control of the Energy Risk ................ 70

PART TWO:

TENSE RELATIONS AMONG ECONOMIC POWERS $\ldots \ldots \ldots \ldots \ldots \ldots \ldots$

3. International Trade: The New Insecurities . . . . . . . . . . . . . 77

Declining Growth on Exchanges and Sectoral Crisis ............. 77

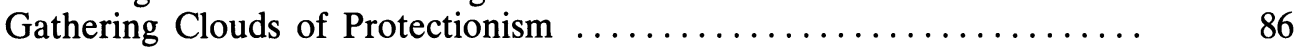

The New Focus of Competition $\ldots \ldots \ldots \ldots \ldots \ldots \ldots \ldots \ldots \ldots \ldots \ldots \ldots$

The Geopolitical Implications of East-West Trade ............... 100

Security and the Food Supply Problem ................... 111

4. The New Equations of Monetary and Financial Insecurity . . . . . . . . 117

The Cost of Wide Currency Flutuations ................... 118

System Risk: Euromarkets and Financial Hierarchies ............ 125

"Country Risk": Third World Deficits and Polish Negotiations ....... 134

The Crisis in the Multilateral Institutions .................... 145

Financial Security and the Dialogue Between Lenders

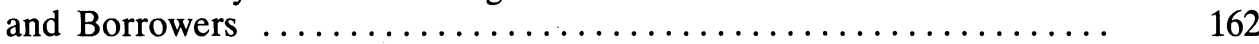


PART THREE:

ECONOMIC PERFORMANCES AND POLICIES: THE BREAKDOWN OF CONSENSUS

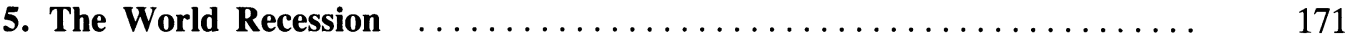

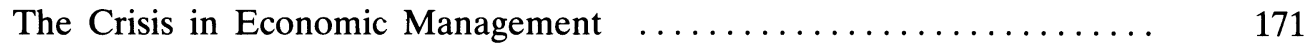

The Public Finance Debate ............................ 175

Shrinking OPEC Surpluses and Rising Third World Deficits . . . . . . . . 177

The Discouragement of the Experts $\ldots \ldots \ldots \ldots \ldots \ldots \ldots \ldots \ldots \ldots$

6. The Broken Consensus within the Industrialized West $\ldots \ldots \ldots \ldots \ldots \ldots$

The Failings of Monetarism ....................... 185

The Search for New Strategies ........................... 192

Flaws in the German Prototype $\ldots \ldots \ldots \ldots \ldots \ldots \ldots \ldots \ldots \ldots \ldots$

7. The Crisis in the Centrally Planned Economies $\ldots \ldots \ldots \ldots \ldots \ldots \ldots$

The Economic Roots of the Polish Crisis .................. 211

The Soviet Union: Economic Dilemmas .................. 218

PART FOUR:

THIRD WORLD COUNTRIES IN SEARCH OF AN IDENTITY . . . . . . 233

8. From Morocco to Pakistan: The Islamic Fault Line $\ldots \ldots \ldots \ldots \ldots \ldots . \ldots \ldots$

Islamic Fundamentalism on the Rise ................... 235

National Independence, but at What Price? ................. 242

Dreams of Peace Against a Backdrop of War ................. 244

The End of Camp David and Egypt's Isolation ............... 249

9. Oil and Economic Development in the Arab World ................ 255

The Gulf States: The New El Dorados of the East .............. 255

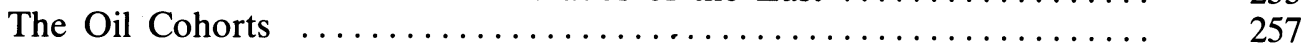

The Failure of Inter-Arab Cooperation $\ldots \ldots \ldots \ldots \ldots \ldots \ldots \ldots \ldots . \ldots \ldots$

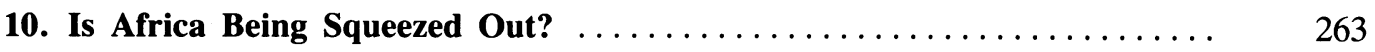

Sub-Saharan Africa Under Scrutiny ....................... 264

Southern Africa Poised Between War and Development .......... 268

Dependence: An Obstacle to Development ................ 276

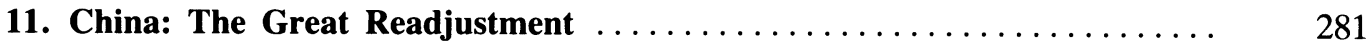

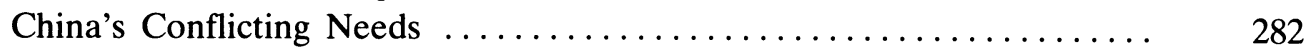

Private Enterprise to the Rescue $\ldots \ldots \ldots \ldots \ldots \ldots \ldots \ldots \ldots \ldots \ldots . \ldots \ldots$

Improving Living Standards: The Challenge of the Eighties ........ 283

The Problems of Looking Outward ..................... 284

The Challenge of a Growing Population $\ldots \ldots \ldots \ldots \ldots \ldots \ldots \ldots \ldots . \ldots \ldots$

Education: A Prerequisite for Progress $\ldots \ldots \ldots \ldots \ldots \ldots \ldots \ldots \ldots \ldots . \ldots \ldots$

Oil: From Daqing to the Sea of Swallows $\ldots \ldots \ldots \ldots \ldots \ldots \ldots \ldots \ldots$

12. The North-South Dialogue and Economic Security $\ldots \ldots \ldots \ldots \ldots \ldots \ldots$

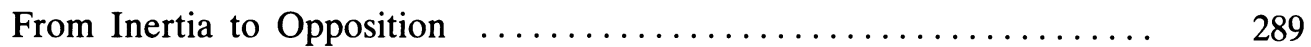

The Fight for Global Negotiations . . . . . . . . . . . . . . . . . 294

The Paris Conference on the Least Developed Countries .......... 297

The Scope and Limitations of South-South Cooperation ........... 302

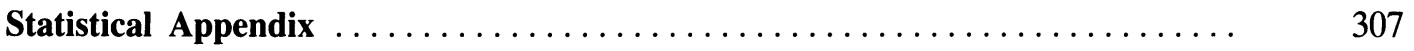

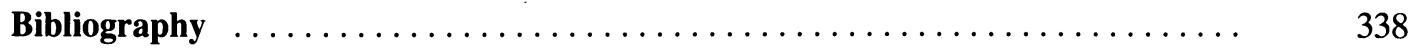

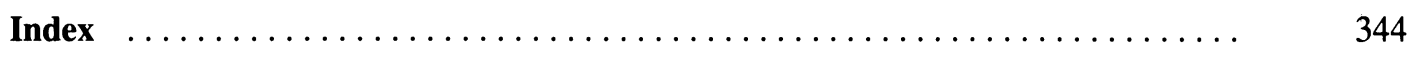




\section{LIST OF ILLUSTRATIONS}

\section{Chapter 1. World equilibrium and European security}

The President, the Congress and the U.S. defense budget .............. 16

Social and military programs in the American budget .................. 18

Main suppliers and importers of heavy weapons systems $(1977-1980) \ldots \ldots \ldots .22$

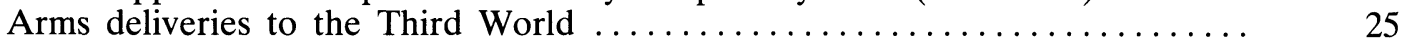

Chapter 2. In search of energy security

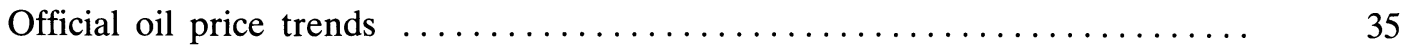

Term tanker charters: the growth of the national companies $\ldots \ldots \ldots \ldots \ldots . \quad 39$

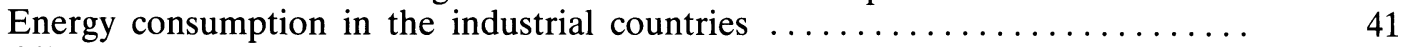

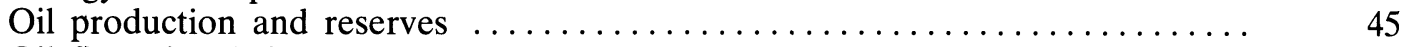

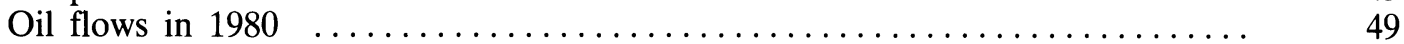

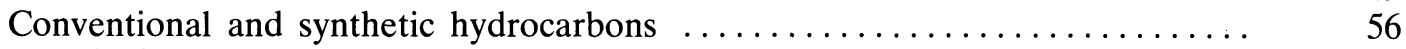

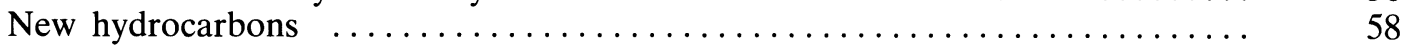

Chapter 3. International trade: the new insecurities

Growth in world exports and production of manufactured goods

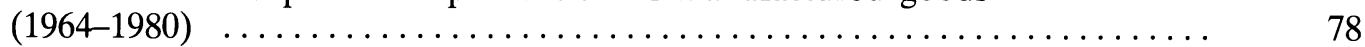

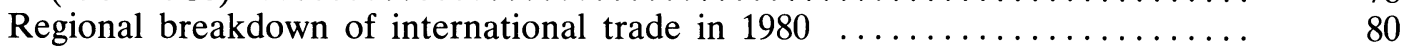

Market shares in 1980: semiconductors and computers ................. 90

Exports of manufactured goods to Third World countries: The growth of South-South

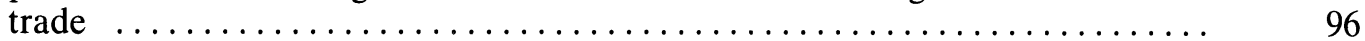

The predominance of Asia in South-South trade $\ldots \ldots \ldots \ldots \ldots \ldots \ldots . \ldots 9$

Chapter 4. The new equations of monetary and financial insecurity

The gold-dollar price mirror effect $\ldots \ldots \ldots \ldots \ldots \ldots \ldots \ldots \ldots \ldots \ldots, 121$

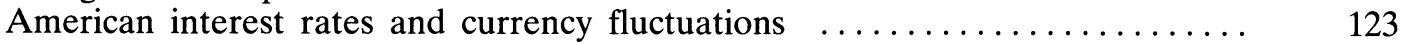

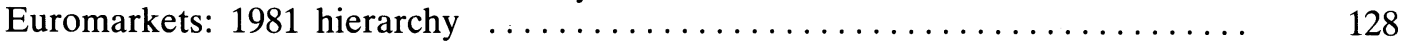

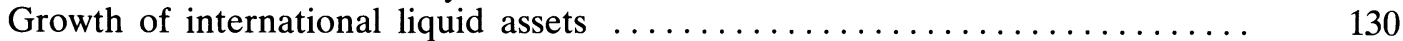

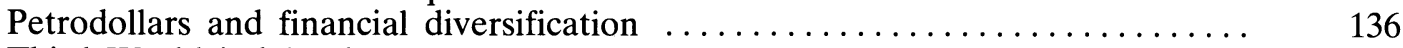

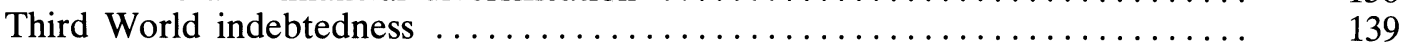

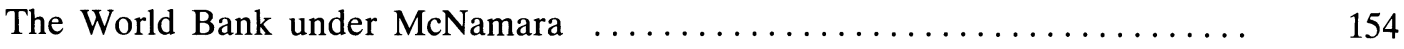

Chapter 5. The world recession

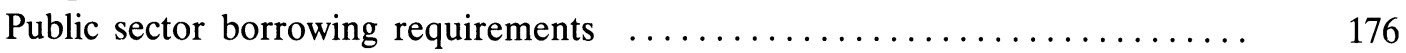

Chapter 6. The broken concensus within the industrialized West

Current-account balance and trade balance of the Federal Republic of Ger-

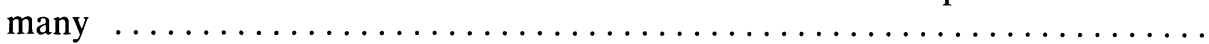

Chapter 7. The crisis in the centrally planned economies

The Soviet Union's declining performances $\ldots \ldots \ldots \ldots \ldots \ldots \ldots \ldots \ldots . \ldots 221$

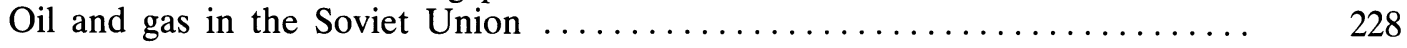


Chapter 8. From Morocco to Pakistan: the Islamic Fault Line

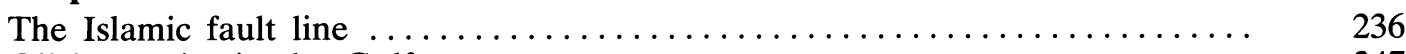

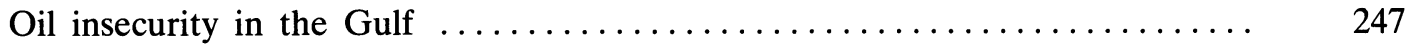

Chapter 10. Is Africa being squeezed out?

Southern Africa: buffer or developing country community $\ldots \ldots \ldots \ldots \ldots \ldots .270$ 


\section{LIST OF TABLES}

Chapter 1. World equilibrium and European security

The Balance of Forces on the Eve of the Geneva Negotiations of November

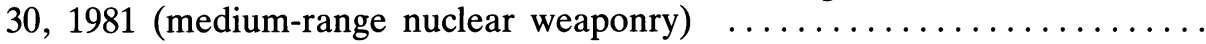
Estimates of the Defense Share of Soviet GNP, Comprehensive Military Out-

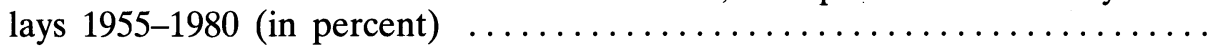

\section{Chapter 2. In search of energy security}

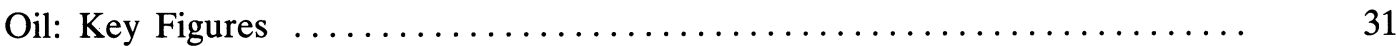

Oil Production in OPEC Countries (million barrels per day) ............ 32

Drop in Oil Prices at the OPEC Meeting in Abu-Dhabi, December 9-11,

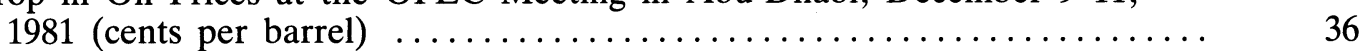

Growth and Energy Consumption in the Main Industrial Countries ........ 40

Decline in Oil Consumption in the Main Industrial Countries, $1981 \ldots \ldots \ldots .42$

Capital Investment and Exploration Expenditure (\$billion) $\ldots \ldots \ldots \ldots \ldots \ldots .44$

U.S. Oil Production (million barrels per day) $\ldots \ldots \ldots \ldots \ldots \ldots \ldots \ldots \ldots . \ldots \ldots$

Exxon's Research and Development Expenditure, $1981 \ldots \ldots \ldots \ldots \ldots \ldots . \ldots . \ldots 2$

IEA and EEC Emergency Programs $\ldots \ldots \ldots \ldots \ldots \ldots \ldots \ldots \ldots \ldots \ldots \ldots \ldots \ldots, 68$

\section{Chapter 3. International trade: the new insecurities}

International Trade by Major Areas (percentage of world exports) ......... 79

World Trade by Commodity Groups (percentage of world exports) ........ 79

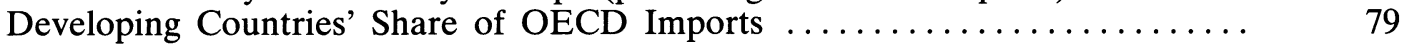

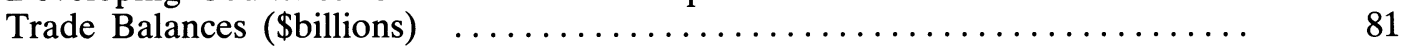

Trade Balances of the United States and the EEC with Japan (\$billions) .... 82

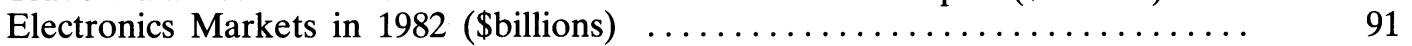

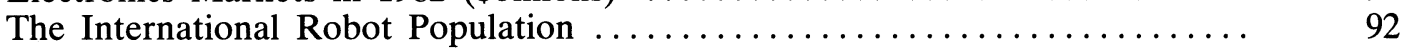

The Top Ten Semiconductor Companies $\ldots \ldots \ldots \ldots \ldots \ldots \ldots \ldots \ldots \ldots . \ldots \ldots$

Intercontinental Trade of Manufactured Goods in 1979 .............. 97

Manufactured Exports from Some Developing Countries to the South (\$bil-

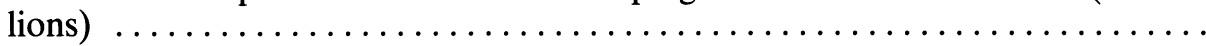

Share of Fuel Imports in Total Western Imports from Eastern Countries,

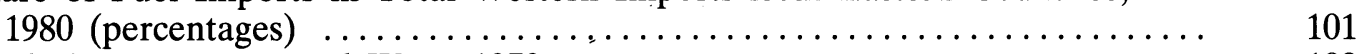

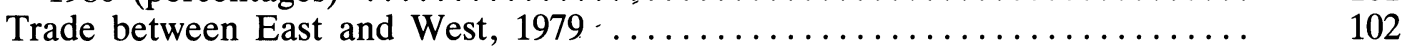

Per Capita Meat Consumption in 1977 (kilos) ...................... 104

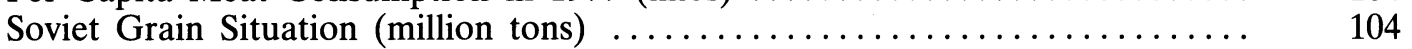

Deliveries by Main Suppliers to the Soviet Union, January-September 1980

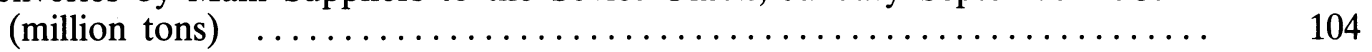

Share of Western Countries in Total OECD Exports to the Soviet Union

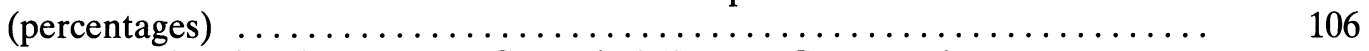

Share of Soviet Gas in Western Countries' Energy Consumption

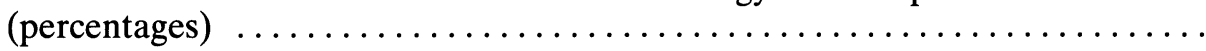


Chapter 4. The new equations of monetary and financial insecurity

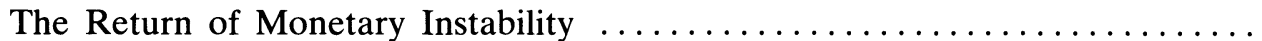

Share of Dollar in Eurobond Issues (percentages) $\ldots \ldots \ldots \ldots \ldots \ldots \ldots \ldots$

Currency Shares of Foreign Holdings Reported to the BIS (percentages) ....

Concentration of Long-Term Debt of Developing Countries (end of 1980) ...

The Decline in Bond Financing for the Developing Countries $\ldots \ldots \ldots \ldots \ldots$

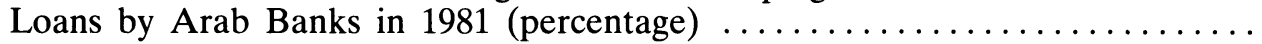

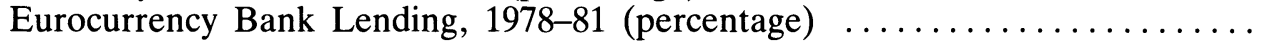

Largest Borrowers of Arab-Arranged Credits, 1976-81 ...............

Most Important Creditors of Poland (percent share of medium- and long-term

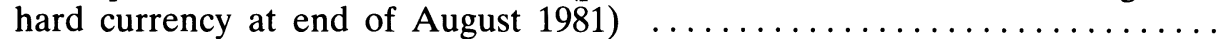

The Financial Role of The International Monetary Fund, November 1981 ..

Distribution of Votes in the IMF (percentage) $\ldots \ldots \ldots \ldots \ldots \ldots \ldots \ldots \ldots$

The Sixth IDA Replenishment Jeopardized by the United States (\$million) ..

\section{Chapter 5. The world recession}

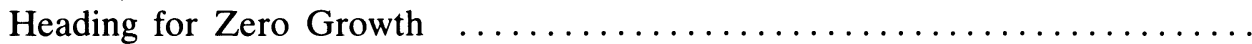

Unemployment in OECD as Percentage of Active Population ..........

Use of the NCI in 1980 (millions of ECUs) $\ldots \ldots \ldots \ldots \ldots \ldots \ldots \ldots \ldots$

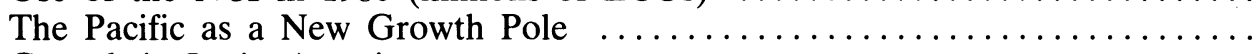

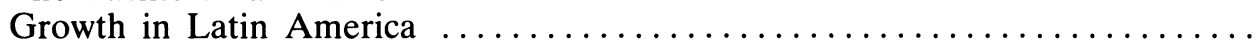

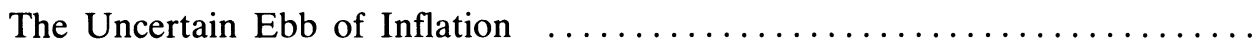

OPEC's Balance of Payments on Current Account (\$ billions) ............ Current Account Balances of Major OECD Countries (\$ billions) $\ldots \ldots \ldots$. Non-oil Developing Countries: Financing of Current Account Deficits and

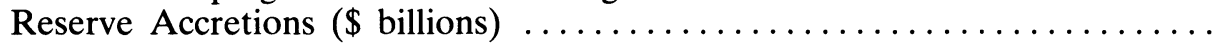

\section{Chapter 6. The broken consensus within the industrialized West}

United Kingdom: Three Years of Monetarism $\ldots \ldots \ldots \ldots \ldots \ldots \ldots \ldots \ldots$

Economic Assumptions of the Reagan Program, February 18, $1981 \ldots \ldots \ldots \ldots .189$

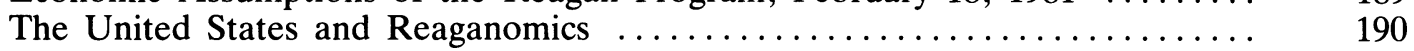

Importance of Public Firms in Certain Industrial Countries . . . . . . . . . 196

Current German Balance (in billions of marks) ..................... 199

Public Finance and Internal Debt (millions of marks) $\ldots \ldots \ldots \ldots \ldots \ldots \ldots \ldots . \ldots \ldots$

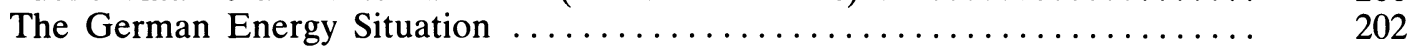

Hours Worked in the Major Industrialized Countries . . . . . . . . . . . 203

Forty Million Germans in the Year 2030? ........................ 204

Students Preparing for an Engineering Career (percentage) $\ldots \ldots \ldots \ldots \ldots \ldots . \ldots . \ldots . \ldots . \ldots 204$

Electronics Production in Europe in 1978 (\$ billions) $\ldots \ldots \ldots \ldots \ldots \ldots \ldots .206$

\section{Chapter 7. The crisis in the centrally planned economies}

The Slowdown in Economic Growth in Eastern Countries ............

Evolution of Labor Productivity (ratio of net national production to employment in material production sectors, expressed as percentage of annual average variation)

The First Half of the Gierek Decade-Rapid Growth (growth rate in volume

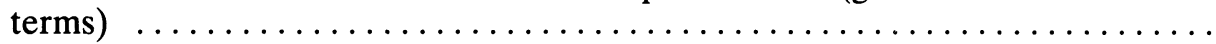


The Rate of Growth of Poland's External Trade with the European CMEA Countries (first three quarters of 1981 as opposed to the first three quar-

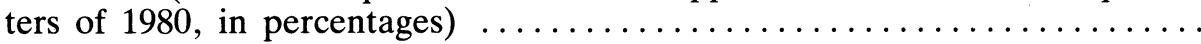

Balance of External Trade in 1980 for Four Countries of the Eastern Bloc

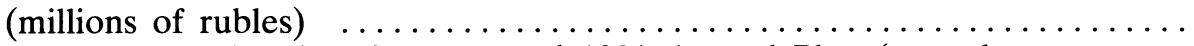

Main Indicators for the Five-year and 1981 Annual Plan (annual percentage

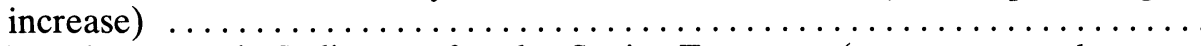

Selected Economic Indicators for the Soviet Economy (average annual rates

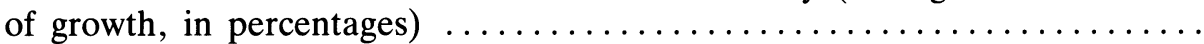

Projected Production Targets in the Eleventh Five-Year Plan .............

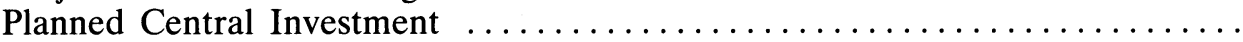

Consumption-Related Goals for $1980-85$ in the Draft Eleventh Five-Year Plan

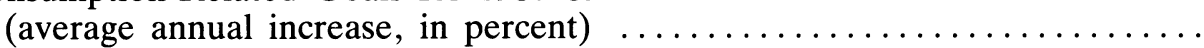

Projected Energy Target in the Eleventh Five-Year Plan $\ldots \ldots \ldots \ldots \ldots \ldots$.

Nationalities in the Soviet Union: Demographic Aspects .............

Relationship of Economic Growth to Energy Use (increments expressed in

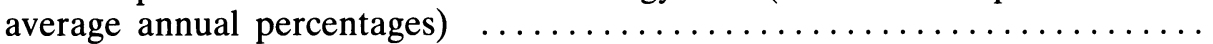

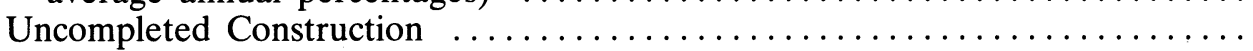

Chapter 9. Oil and economic development in the Arab world

Per Capita GNP in Four Arab Countries in Africa (in 1979 dollars) . . . . . . Non-Oil Economies

Chapter 10. Is Africa being squeezed out?

Growth of African Countries and Developing Countries (percentage) .....

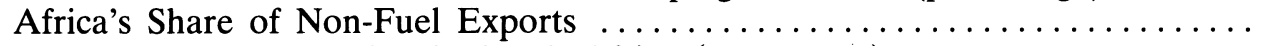

Breakdown of Population in South Africa (percentage) $\ldots \ldots \ldots \ldots \ldots \ldots \ldots . \ldots \ldots$

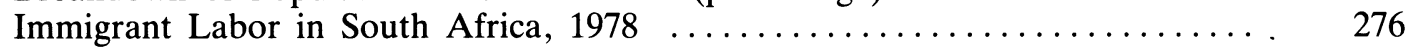

Chapter 11. China: the great readjustment

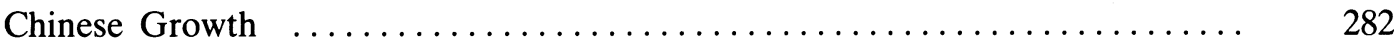

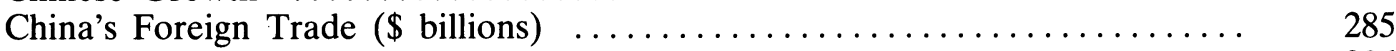

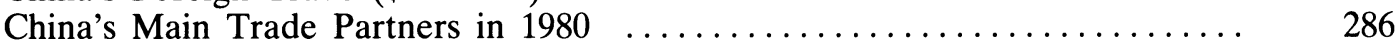

The Population of China in the Year Two Thousand $\ldots \ldots \ldots \ldots \ldots \ldots \ldots .286$ 


\section{FOREWORD}

Not many Americans are familiar with the French Institute for International Relations (IFRI), yet this relatively small institution in Paris has earned the high regard of those familiar with its work and has distinguished itself with very timely publications and conferences. Two years ago its staff of bright, young academics and practitioners on leave from government prepared an annual report on the world economic system (RAMSES). The success of the first report and the freshness of its analysis from a European perspective led to the decision to prepare an English version of the second report to make it readily available to Americans. I trust that readers will now discover these qualities for themselves.

International economic conflicts in the 1980s are likely to increase. The rise of protectionist pressures, monetary fluctuations, and conflicting national economic policies are not new features of international relations, but as the point is made time and again in this report, they now take place against a background of lower economic growth and reduced organization in the fabric of international and, particularly, transatlantic cooperation. These conflicts also take place at a time of rising economic nationalism, the return to more ideological policies in a number of important countries, and a diminished role for many of the specialized international organizations that were once expected to provide guidance to national decisionmakers. Countries held as models only a few years ago are now confronting difficult questions regarding their strategic security and the value systems underpinning their past achievements.
In this context the global approach characteristic of the RAMSES report is an indispensable complement to more specialized economic work. IFRI's assumption that economic relations can only be understood in the perspective of the broader political relations between nations is particularly relevant at a time when many international regimes are shaken and new ones are yet to emerge. In such periods boundaries between issues and between analytical disciplines become fluid. Neither economists nor political scientists have a monopoly on wisdom. The international political economy approach of the RAMSES report helps to fill an important gap. RAMSES draws on specialized work when appropriate and presents original studies in critical fields where they are most needed; note, for example, the sections on the economic roots of the Polish crisis, on the rise of Islamic fundamentalism outside of Iran, on the difficulties facing Germany, and on the growth of South-South trade.

Aside from its specific analytical insights on the world economic scene, the IFRI report is particularly interesting to an American audience because of its European approach. Now that transatlantic relations are often plagued by subtle and unspoken misunderstandings, this French effort to communicate an overview of the world situation is especially welcome. RAMSES is already the result of a process of cooperation; it involves several American writers, and key chapters have been discussed on this side of the Atlantic. But it conveys a different sense of priorities, vulnerabilities, and opportunities that help to challenge purely American approaches. 
In the field of energy, for example, there is much more interest in consumer-producer dialogues and North-South cooperation than is typical of most American analyses. Similarly, the emphasis given to monetary stability or to protecting non-American banks against the "system risk" associated with the growth of the Eurodollar markets reminds us of the international significance of American policies that the Reagan administration, this report suggests, views from a narrow, even parochial perspective. In short, this report is a healthy corrective to our tendency to see the world entirely through American lenses. I believe the American reader will learn from this report in more ways than one.

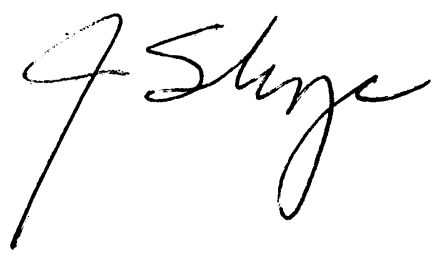

Joseph S. Nye

Kennedy School of Government Harvard University 


\section{PREFACE}

The publication of RAMSES 82: The State of the World Economy is a welcome opportunity for us to present policymakers, experts, and the interested public in the United States and the English-speaking world with research being carried out in a new and unique French institution. Founded in 1979, the French Institute for International Relations (IFRI) combines academic freedom with a close relation to the foreign policy community, providing that community with an unprecedented forum for informed discussion and research on international relations. IFRI is a nonprofit, independent organization and decides its own work program free of governmental control. Its major counterparts in the West are the Council on Foreign Relations in New York, the Royal Institute for International Affairs (Chatham House) in London, and the Deutsche Gesellschaft für Auswärtige Politik in Bonn. (In 1981 the four directors of these institutions published in their personal capacity a report on Western security). ${ }^{a}$

Among IFRI's present activities, extensive research is being conducted on European security and pacifist trends, the economic and military situation in Asia and the Middle-East, Africa, and developments in Southern Asia. Our review, Politique Etrangère, antedates the creation of our institute by more than thirty years and provides the French-speaking audience with the counterpart to Foreign Affairs.

Yet RAMSES is certainly the most ambitious and original of IFRI's programs. It attempts to provide both a reference tool corresponding to the needs of private and

a. Western Security: What Has Changed? What Should Be Done? by Karl Kaiser, Winston Lord, Thierry de Montbrial, David Watt. public decisionmakers and a vehicle for indepth analysis of contemporary economic issues.

The first RAMSES report was prepared and published under the direction of Albert Bressand in the spring of 1981. It has been very warmly received by the public as well as by the economic and social science communities. (It won a prize from the prestigious Académie des Sciences Morales et Politiques.) Nevertheless, it was necessary to give this report a truly international dimension. It is therefore with great pleasure that we present an English language version of the second RAMSES report.

It was a very challenging task to create the functional equivalent of RAMSES for an American audience while preserving the unique character that stems from its synthesizing approach and its emphasis on the politics of economic relations. RAMSES now appears as the product of a truly European vision of the world.

We know of course that this task has only begun, and we are counting on the reaction to this first report in English to help us come closer to our objectives. Thanks to the help we have received from numerous friends in the United States, this endeavour has been rendered much easier and more pleasant. Needless to say, all remaining shortcomings and errors can only be attributed to IFRI.

Among the American contributors who have agreed to take part in this unusual undertaking, James $K$. Galbraith deserves very special thanks. He played the invaluable role of critical reader for the entire report and has provided numerous and useful comments on the structure of the American version. In addition to his own work in the energy field, Pierre Jacquet, IFRI's representative in the 
United States, has had the exhausting task of managing an adaptation process that involves much more than translation.

As we do in France, we have also begun to organize in the United States a systematic discussion process around the major chapters of this book in order to benefit from expert review and criticism. In the field of energy, our work has benefited immensely from the friendly cooperation of the Harvard Energy Security seminar and most notably of Alvin Alm, William Hogan, Henry Lee, and Joseph Nye. Comments by John Holdren and Edward Krapels have also enriched these sections considerably. Other chapters have similarly benefited from detailed comments by Fred Bergsten, Albert Carnesale, Benjamin J. Cohen, Richard Cooper, Dan Dimancescu, and Peter Kenen.

In trying to organize this review process, but also in all other aspects of the work related to this American edition, we have found at Ballinger Publishing Company the warmest and most efficient help we could ever have expected from every member of the staff. It is very unusual indeed that relationships between authors and publishers acquire the quality of genuine cooperation. We want to express our warm thanks to Michael Connolly, Gerald Galvin, Steven Cramer, Molly Andrews, Barbara Roth, and particularly to Carol Franco. It is difficult to express adequately our immense thanks to her, since we now feel that she is and always has been a full member of the project management team. Let us say simply that the book would not have been possible without her.

Financing this ambitious project and giving it an international dimension has been made possible in part by a grant from the German Marshall Fund, to which I want to express our deepest appreciation.

It is with great pleasure that I take this opportunity to thank all those who have made this work possible, especially Albert Bressand, who not only designed the project but directed each aspect of it with the greatest effectiveness. He and the team gathered around him have devoted endless effort and enthusiasm.

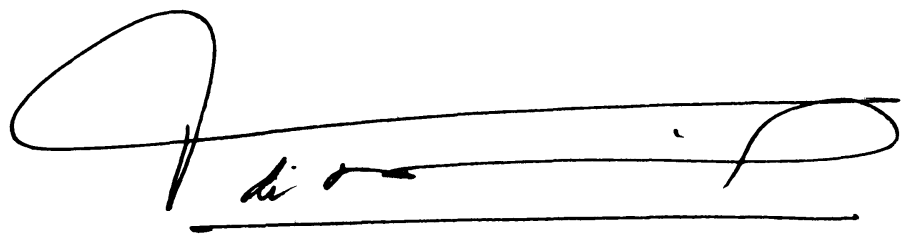

Thierry de MONTBRIAL

Professeur à l'Ecole Polytechnique Directeur de l'IFRI 
Introduction

From the hall of winds to the hall of mirrors

At Jaïpur there is a majestic palace whose long pink facade soars skyward. Five tiers of arches and porticos with fine stone filigree screens bear testimony to the tireless, meticulous work of an entire generation of craftsmen, laborers, and architects. At either side rise turrets from which one can imagine a view over the mountains of Rajasthan. A lofty wall seems to guard intact the power of the maharajahs. Yet, should one venture to approach any of the five doors, one is surprised to discover that the monument is no more than a facade. This "Hall of Winds" is uninhabited and always has been, except perhaps in the dreams of a prince who has now disappeared from memory.

The palace of Versailles, chosen to host the latest Western economic summit in June 1982, is, happily, of more robust construction. This quality, however, did not necessarily extend to the intellectual construct painfully elaborated amid the confusing play of images in the "Hall of Mirrors." Despite the progress made on certain highly complex and conflicting issues, the ambiguities of the communiqué were heightened by the diverging interpretations that some delegations were quick to put on record.

As in Jaïpur, the winds of history seemed to be howling through an exceedingly fragile edifice. Unforeseen crises-in Lebanon, in the Gulf, and in the South Atlantic-raised serious doubts about the capacity of Western leaders to master the complexities of an increasingly dangerous world, or even to influence the attitude of such close allies of the United States as Israel and Argentina. Seldom have so many symbols of power coincided with so little control over events as in the palace of the Sun King.

A large part of this loss of collective control over events stems from what General de Gaulle would have called "the nature of things." Indeed, to use the more mundane language of the technocrats, "diffusion of power" has been at work in the present international system almost since it was created at the end of World War II.

In the military field, this trend toward a less manageable system was evident in the inability of the United States to win the war in Indochina. More recently, it can be seen in the continuing heavy losses inflicted upon the Red Army by the archaic weaponry of determined Afghan Freedom Fighters or in the surprisingly heavy price the British armada has paid to recapture the Falklands from a Latin American junta. Nuclear proliferation might well make these difficulties appear in retrospect as minor irritations.

In the economic field, diffusion of power has also been at work for several decades. Newcomers have joined the ranks of the industrialized nations, and new power centers have emerged in the fields of energy, finance, and trade, adding to the complexity of an economic system becoming at once more integrated and more diverse.

But the West's dismal track record in managing the system has other roots too, traceable to straightforward policy failures. The failure in the early 1970 s to account for the new constraints and opportunities of interdependence were attributed by many to the incapacity of increasingly bureaucratic international organizations to generate the "political will" required for major policy changes. 
Hence the creation, notably under French pressure, of the "European Council"" (which offers the opportunity for relatively informal contacts between EEC heads of state) and of the Western economic summits that provide a highly flexible forum in which the seven most powerful Western leaders can thrash out issues of common concern. Unfortunately-with the possible exception of Bonn in 1978 and Tokyo in 1979summits have too often remained a juxtaposition of national monologues.

President Carter viewed summits as one ingredient in his attempt to generate support for his policies at home-a narrow view of international cooperation. Reagan managed to weather the Ottawa summit and the Cancun NorthSouth summit by skillfully handling the only dimension that really mattered to him: the intense but ephemeral impact such meetings can have on the several thousand "summit watchers." One may wonder whether the Reagan administration's position at Ottawa and Versailles would have been very different had these meetings taken place in the 1950 s, before economic interdependence had assumed such dramatic proportions. The Reagan administration's singleminded emphasis on East-West trade considerations, to the detriment of North-South and even West-West issues, is a sign that its world view has yet to take into account the degree to which national policies necessarily affect one another.

But the United States is certainly not the only country at fault. The overriding Japanese objective, in any such gathering, is to prevent trade discussions from proceeding past a symbolic show of support for "free trade" defined in the most general terms. This low-profile policy is all the more regrettable because the remarkable successes of Japan (now the world's second economic power after the United States) demand a more active participation in the process of economic and political management.

The French, for their part, spared no effort to make Versailles a success. Yet their professed internationally minded approach too often includes a tendency to ascribe universal relevance to French domestic values and policies. One good example is the French plan to revitalize European cooperation by applying the Socialist policy of work-time reduction on a European scale. This well-thoughtout proposal stands little chance of being accepted by the Thatcher and Schmidt governments.

Crucially dependent on an open world market in which it is well equipped to compete, Germany is understandably one of the strongest advocates of economic cooperation. But as international economic problems acquire an increasingly political or strategic dimension-East-West trade being a case in point-the special constraints still limiting Germany's political and security role impede its capacity to exercise the kind of gobal influence now required. Furthermore, even in purely economic terms, the role of a "locomotive" assigned to Germany by its partners at the 1978 Bonn summit left sour memories since it is seen to have aggravated a disquieting public debt problem.

It is therefore hardly surprising that the conclusions of the Versailles summit tend to evoke Jaïpur's Hall of Winds rather than the monumental solidity of Louis XIV's architecture. On the other hand, in the present context of mounting economic nationalism, Versailles nevertheless brought together governments and bureaucracies to address major international issues and even allowed limited progress on some of them. The main threat to the world economy, as underlined in this report, is the gradual erosion of the fabric of international cooperation and of the institutional "architecture" on which it rests. The majesty and solidity of the sevententh-century palace has at least illustrated the importance of what is at stake.

\section{The ascent of economic nationalism}

Skeptics will cavalierly dismiss these failures of international economic coop- 
eration, or even the idea of such cooperation, as of little significance. But however deep-rooted it may be, contempt for international economic cooperation is ill-advised. Today's unemployment and inflation can no longer be fought solely on the home front. The depth of the American recession of 1981-82 is in large part due to the dismal U.S. export performance, resulting from both the world slump and the overvalued dollar. Similarly, the failure of the French socialist government to achieve the higher growth rate at the center of its electoral platform is a reflection of the external constraints that a slow-growth, high interest-rate environment represents for Keynesianminded decisionmakers.

Although the failure of domestic economic policies tends to diminish public and governmental interest in international issues, exactly the opposite is needed. Domestic economic policies do not produce the expected results-in Reagan's United States as well as in Mitterrand's France-because the crisis that national economies suffer is largely an international crisis. There is little point in waiting for a "new Keynes"either from a conservative supply-side southern California college or from a Marxist-oriented European milieu-to spell out the new gospel of prosperity. Our difficulties are the direct consequence of the deterioration of an international framework that few economists even mention in their work.

Not only is the international dimension of the crisis improperly addressed, but our collective capacity to deal with it seems to be diminishing. A few years ago, the "management of interdependence" was at last being seen as a priority and timely undertaking. The global challenges were considered in a positive perspective as the natural counterpart to the unprecendented prosperity an open international system had allowed. U.S. diplomacy was still informed by the will to contribute to the organization of international relations. This role was brilliantly played at the end of World War II and is the essence of true leadership. From Stockholm to
Bucharest, from Rome to Mexico, the United States advocated a global approach to the world wide challenge of environmental pollution, overpopulation, food production, and the dignity of women.

Europeans were also still living in the momentum of three decades of unprecendented growth during which their ruined economies had been reconstructed and raised to levels approaching those in the United States. Europe's leaders could be taken seriously when they vowed-as they did at the Hague in 1972-to move from economic integration to "political union" before the end of the decade. In spite of persistent poverty, new forces for growth were emerging in Latin America and Asia. A "poverty curtain" still divided mankind into two very different worlds, ${ }^{1}$ yet the working assumption was that the old scourges of hunger and poverty could be gradually eliminated. Three times in less than twelve years, Robert $\mathrm{McNa}$ mara marshaled political support to double World Bank efforts. Third world countries accustomed to perceiving the Bank as an American instrument began to see it differently. More generally, the launching of a West-South dialogue (misleadingly labeled "North-South") had strategic significance because the Soviet Union was unable to offer any significant help other than secret police and weaponry.

This spirit is a thing of the past. The gulf between the nations widens as they pursue divergent national policies in ignorance of their mutual impact. In the aftermath of the second oil shock, the Western world concurred on the need to give priority to combatting inflation by controlling monetary aggregates. Now that consensus has been challenged in the recent elections and political debates, both from the supply-side perspective in the United States and the Socialist or social democrat camp in Europe. As we noted in our first report, this consensus reflected a scaling down

1. Mahbub ul Haq, The Poverty Curtain: Choices for the Third World (New York: Columbia University Press, 1976). 
of economic policy ambition. However, the economic voluntarism, which public opinion increasingly expects, is expressed in very different terms depending on the country concerned. In the United States, the object is to liberate market forces by reducing the various forms of government intervention. On the other hand, France intends to achieve a gradual break with capitalism, at least in theory. Its ambitious industrial strategy is organized around a vast program of nationalization. West Germany seeks a compromise-difficult to achieve both economically and politically-between a budgetary effort to stimulate the economy and improved control of public finance.

The great differences between them notwithstanding, the new French and American governments resemble one another in their attempts to limit the influence of the international environment on their policies. The leitmotiv in Paris is "nationalize to avoid internationalizing" while U.S. diplomacy is singularly colored by domestic economic goals.

This change of perspective is all the more radical in that the international situation no longer provides a model for defining a common strategy. For many years West Germany was lionized as an example, and even today it continues to manifest remarkable commercial vitality. Yet it is now paying the price for the many years when the mark was overvalued, and it must struggle to catch up in the electronics race. Perhaps more fundamentally, the value system supporting the "German miracle" has been undermined by the threefold pressure of economic prosperity, reluctance to adopt new technologies, and strategic insecurity.

\section{The world recession}

More than a year after Ronald Reagan and François Mitterrand came to power, it is now apparent that while their basic philosophies are fundamentally opposed, these differences are much less clear in the day-to-day im- plementation of macroeconomic policies.

The conceptual originality of Reaganomics has come to nothing. Its failure to bring about a rapid resumption of growth conjures up, once again, the disgraced spectre of Thatcherism. As "supply-siders" one after the other left the administration, and growth forecasts were being revised downward, the policy gradually emerged as fairly conventional monetarism. In spite of impressive results in reducing inflation, the reversal of expectations anticipated as a result of firm monetary policy has not materialized. The economic and social costs of this type of policy are just as high as in the United Kingdom. A European viewpoint questions the wisdom of an approach that allows an unemployment rate of 9.4 percent in the population as a whole and of about 50 percent in young blacks. Moreover, it coincides with an effort to dismantle rather than reform a social security system that was already one of the least coherent and comprehensive in the West. Even if judged by its own standards, the administration may be reducing direct government intervention in the economy only to increase its indirect role, particularly in the financial markets. In its latest June 1982 report, the BIS puts total budget and nonbudget federal financing needs at about 35 to 40 percent of total national gross savings, a figure that highlights the risk of "crowding out" private investment through higher interest rates. ${ }^{2}$

France has to reckon with external constraints in which room for maneuver in budgetary questions bequeathed by the Barre government has proved limited. Admittedly, one might accept the foreign trade deficit as necessarily accompanying strong resumption of activity in a depressed international environment. But in addition to this financial constraint, the Socialist government must also confront monetary constraints produced by a combination of abnormally high U.S. interest rates

2. Bank for International Settlements, Annual Report, June 1982. 
and a domestic rate of inflation that though similar to earlier levels-is now between two and three times the levels in the United States and Germany. The 10 percent devaluation of the French franc against the mark on June 12, 1982, has thus been accompanied by a belttightening, anti-inflation policy package that is, here again, quite at odds with the initial declarations.

More generally, the spectacular slowdown in U.S. inflation, coupled with high interest rates, leaves European countries with little room for maneuver. Hence, these countries must either adopt high interest rates that will generate unemployment, or accept a devaluation of their currencies that will fuel inflation. In this situation, they fear that the hierarchy of "strong currency" and "weak currency" countries, which had become blurred after the second oil shock, may once again emerge.

On the whole, the dominating trend is the geographical extension and, within each country, the deepening of a recession that the widely expected cyclical American "recovery" is unlikely to reverse. Budget deficits in the West and the skyrocketing cost of debt servicing in the South act as powerful brakes even on economies such as Brazil's and Mexico's that had provided throughout the 1970s welcome engines of growth for international trade. Even the once buoyant OPEC markets are experiencing stabilization or even shrinkage resulting from depressed oil markets. The Pacific basin appears as the last outpost where the spirit of growth still lives, but for how long? The risk is that the deepening of the recession is gradually underminingthe domestic and international mechanisms on which the management of the economy depends. This "crisis of regulation" may in turn pave the way to perils our collective memory associates with the 1930 s.

\section{The whittling away of the interna- tional organizations}

The problems that afflict summit conferences are all the more ominous be- cause they merely form the visible part of a general process of erosion, to use Joseph Nye's concept, ${ }^{3}$ of the present "international ,organization." The network of institutions, norms, and "regimes" designed to provide the essential political framework for an integrated world economy, a sine qua non for its survival, is indeed gradually disintegrating.

In appearance, of course, the edifice on which international economic security has rested since the end of World War II still starıds. In appearance, the GATT fortress still commands the paths down which the forces of protectionism might surge. In appearance, the twin citadels of the IMF and the World Bank keep close watch over the liquidity of the financial system, exchange-rate policies, and the solvency of the poorest countries. In appearance, the major industrial democracies have established a joint pax economica that is policed from the castles of the OECD, the BIS, and the EEC. In these lofty places, solemn masses are sung to the glory of cooperation and free trade. For eight years now, at the return of the summer solstice, the leaders of the seven most powerful nations meet, as they did in Versailles, for even more solemn rites during which the most secret and elusive of our economic tutelary deities, "political will," is reputed to manifest itself to the initiated.

Yet the solemnity of this ritual provides an increasingly fragile bulwark against the exercise of naked power. While the reassertion of basic principles may patch this bulwark, the repetition of dogma simply serves to mask mounting confusion.

In spite of the prestige they retain, the influence of the major institutions such as the IMF, OECD, and EEC, is gradually diminishing. Their role is soon likely to resemble some latter-day Maginot Line manned by elite troops unaware that the battle will be fought elsewhere. The United States, at whose

3. Joseph S. Nye and Robert O. Keohane, Power and Interdependence: World Politics in Transition (Boston: Little, Brown, 1977), p. 54. 
instigation many of these institutions were founded, now does everything to reduce their role and cut back their resources. Not only is the United States jeopardizing the financing of the International Development Association, the World Bank's "soft window," it also impedes ongoing efforts to provide these institutions with a function relevant to the conditions and priorities of the world today. By opposing a revamping of "conditionality" and direct recourse to capital markets at the IMF, and by stalling the much-needed "energy affiliate" project at the World Bank, the United States contributes to the loss of influence of these organizations, despite its declaration that they "contribute significantly to the achievement of U.S. long and medium term political/strategic interests." 4 Meanwhile, the Europeans and the Japanese cannot acquire the influence needed to offset the relative decline of the United States. The fluctuating fortunes of the mark and Japan's slow progress in relearning to operate as a political power are good examples. More serious is the paralysis of European institutions, which threatens Europe's ability to make its voice heard in world affairs.

Without a major effort to renovate these organizations-structures erected by a generation acting on lessons learned from the Great Depression and World War II-these institutions will gradually become drained of their substance and relevance. The open international economy as we know it will then rest on an even more fragile base.

\section{Security and interdependence: the quest for a new balance}

Only in quite specific conditions, which today appear increasingly elusive, can interdependence become a source of common prosperity and possible peace. In the international "natural

4. United States Participation in the Multilateral Development Banks in the 1980s (Washington, D.C.: Department of the Treasury, 1982). state," to which we are slowly returning, dependence is a source of vulnerability, maneuvering, and conflicts. In this situation nations look to themselves for a security they cannot find on the open seas of economic liberalism, even at the risk of curtailing their potential.

Despite the various improvements in short-term economic conditons making headlines recently-declining oil prices, diminishing inflation in the United States, the bottoming-out of the recession-the global view of the world economy we present in this report still must be structured around the many risks that continue to loom on the horizon. As we keep underlining, energy, trade, and finance are all beset by economic insecurity. This need not be grounds for despondency. Measures could be taken both nationally and internationally to reduce this insecurity. Indeed, our emphasis is as much on the potential benefits of international cooperation as on insecurity as such.

Insecurity stems from the breakdown of the political consensus on which the economic peace has been based. Therefore, it is by nature a global phenomenon that escapes the kind of narrow economic analysis pursued when the stability of political and strategic frameworks are taken for granted. Insecurity feeds on regional instability. It is fostered by the contradiction between aspirations for economic integration and the reality of cultural differences.

In the long run, there is the danger that tensions may become so closely intertwined that they far exceed the nations' capacity for coordinating efforts to control them. The contradiction between growing political divisions and increasing economic integration, as well as the fusion of strategic conflicts with economic rivalries, cause a type of disorganization that may lead to major crises or war.

The politicizing of economic relations, notably through the use of the "economic weapon," is inevitable when overall relations between countries come under increasing strain. The clampdown of the Soviet Union on its sphere of influence and on the periph- 
ery, the misunderstanding generated by the West's cultural and technological dominance in a growing section of the Islamic world, and even the nationalistic fervor that gripped both Argentina and Great Britain in their war over forgotten islands harking back to another era, have been the most recent symptoms of this politicization. Indeed, as a response to these strategic or political challenges, the United States has come to use embargoes and boycotts as routine instruments of international relations. In doing so, however, it may not fully realize the extent to which it undermines the principles to which it is so deeply attached. As we shall see, economic sanctions have proved more complex and costly to apply than was initially expected.

\section{East-West trade, Poland, and the transatlantic malaise}

In East-West relations the economic weapon appears unlikely to make up for a strategic weakness that demands other remedies, namely, strengthening Western and specifically European defense efforts. The United States rightly calls for more careful behavior regarding the sale of technologies with military potential. But deliberately creating additional difficulties for the Eastern block through an across-the-board reduction of trade is ill-advised for at least two reasons. First, an effective economic weapon is a weapon, and the decision to use it can lead to exacerbation of conflicts that Western nations and public opinion do not want. In this sense, the French prime minister stressed that Europeans should not initiate "an act of war" against the Soviet Union. Second, a tough attitude on sales of civilian technologies and on purchases of natural gas is inconsistent with overall American policy. The United States indeed is strong on measures that have a disproportionate effect on Europe while it shies away, for purely domestic reasons, from restricting its most significant exports, namely grain. By deliberately making life difficult for European firms involved in the construction of the Urengoi gas pipeline, the United States is dashing the hopes raised at Versailles of a common Western stand that would reflect both U.S. and European approaches to dealing with the Russians. For our part, we continue to support the more moderate view that calls for avoiding the trade "weapon" while also forgoing the huge elements of subsidy that some nations-chiefly France and Italy-have introduced into their export policies toward the East. On purely economic grounds the growth prospects of Eastern economies do not justify boosting trade artificially. This only leads to the piling of increasingly shaky debts. The subsidies granted to these countries would be better used if invested in the Western economies or within the more promising framework of North-South exchanges.

The most persuasive argument against an "export-at-any-cost" policy toward the East came from the Soviet Union itself on December 13, 1981, when it brutally suppressed in Poland the perspectives opened by the signing of the August 1980 Gdansk agreements. As we point out in Chapter 7 , there is a fundamental contradiction in Sovietstyle economies turning to the West for advanced technologies while maintaining all their political, social, and economic impediments to productivity and sound management. If not backed with a forceful export strategy, which itself demands profound reforms, the kind of import strategy pursued by Edward Gierek in Poland during the 1970s can only lead to a hopeless mountain of debt. But the Soviet gerontocracy has long since lost the vitality to effect such reforms or even to allow them beyond a specific threshold in Eastern Europe "laboratories."

The fact that ten million Poles joined the ranks of Solidarity and that the instigators of the normalization process called it a "state of war" provided a timely reminder that it is force and force alone that keeps Poland in the disastrous Soviet economic system and sphere of influence.

Therefore, the Western nations 
should follow more prudent credit policies while at the same time keep the door open to an expansion of trade provided that it is accompanied by internal reform in the Eastern economies. Hungary's entry into the Westerndominated International Monetary Fund in May 1982 and the fact that indebted Romania is already a member provide a limited but intriguing testing ground for this strategy. In any case, Washington must remember that a tough stand on East-West trade may well increase the influence of the Soviet Union in Eastern Europe. Trade is definitely not the "arms of peace" that Samuel Pisar once imagined, and it is our responsibility to prevent its becoming one more "arm of war" in a world where these are already in abundant supply.

The hopes crushed by martial law in Poland were not only the hopes of the Polish people. Poland's "area of freedom" within the Soviet empire also seemed to provide grounds for hope in Western Europe. It appeared to offer a geopolitical rationale for the hundreds of thousands of peace marchers who demonstrated in the streets of Amsterdam, Berlin, and London while the U.S. President, untutored in the subtleties of international life, fueled their anger by theorizing about a nuclear war "limited" to their continent. Hence, the opposition to the installation of U.S. nuclear missiles capable of striking the Soviet Union. Ironically, that installation had been demanded in 1977 by Chancellor Schmidt in order to offset the threat of Soviet SS-20's and strengthen the "coupling" between U.S. strategic forces and European theater forces.

Over and above the military and diplomatic dimension, the debate on the security of Europe raises more fundamental questions. The United States is increasingly attracted to the Pacific region, where the economic vitality of the world seems concentrated and with which it already does more trade than with Europe. Meanwhile, the Old Continent seems to be hovering between decline and renaissance, neutralism and messianism. After nearly four decades of relying on others for its security and repressing the idea of war, a confused Europe must now learn again to think the unthinkable. For the time being France is relatively well-shielded from this trauma by the existence of an independent defense capacity, but West Germany remains especially sensitive to this question.

\section{Economic and strategic security: the elusive trade-off}

Accordingly, the problem is to achieve a satisfactory relationship between strategic and economic security. In the United States the deficit of well over $\$ 100$ billion resulting from rearmament, recession, and tax cuts will have grave repercussions on the confidence of investors, the level of interest rates, and the economic situation generally. At the same time, the monetary dogmatism of the Reagan administration places its European allies in an awkward position. High interest rates discourage private investors and create greater demand for public investment even in Mrs. Thatcher's England and Chancellor Schmidt's Germany. This is likely to compromise the necessary effort for military security, as is clearly evidenced by the slowdown in the German defense program. More generally, it is not realistic to call for a strengthening of the Western alliance if the economic policies of one nation are allowed to exacerbate the economic, social, and political difficulties of its allies.

The Soviet Union, which devotes a far higher proportion of its resources to defense, has strengthened its arsenal by taking advantage of the slackening Western defense effort that accompanied détente. But now it may be faced with the same dilemma. The Eleventh Five-Year Plan provides no durable response to its most urgent problems: agriculture and energy. The continued priority given to the arms buildup will be increasingly costly. Will the military, confident in its economic superiority over the civilian sector, take power even 
more explicitly? Such is the opinion of Cornelius Castoriadis, a French leftwing theoretician whose recent and successful book illustrates the growing critical attitude of French intellectuals toward the Soviet Union. ${ }^{5}$ On the other hand, will Brezhnev's successors learn a lesson from the burden placed on the economy and on Soviet citizens and embark upon an overhaul of the economy? The answer is far less certain than is sometimes asserted, if only because of the economic and social dimension to the Soviet Union's long-term security.

The West cannot hope to exercise much leverage on these internal evolutions through the use of economic sanctions advocated in some quarters of the U.S. defense community. Yet a combination of increasing Western military budgets, tightening security-related export control procedures, and a reasonably open trade posture could help decrease the attractiveness of a confrontational policy for Brezhnev's successors. It is time to go beyond the narrow views of security held by the advocates of immediate, unilateral disarmamenttheir understandable horror of war notwithstanding - as well as by the naively militaristic U.S. administration.

\section{Oil glut and energy insecurity}

After the two assaults by the producer countries on the economies of the rich industrial nations, it is now the oil companies' turn to launch an attack on the OPEC warlords. Whatever the International Energy Agency may say, the oil companies did unload their massive stocks onto a market already depressed by the recession in the West and by the success of energy conservation. The market turnaround went even further than could have been expected from these natural reactions to the excessive price rises in 1979-80.

Though they appear to have resisted

5. Cornelius Castoriadis, Devant la guerre (Paris: Fayard, 1981). companies' pressures for decrease in the nominal reference price, the producers are now feeling the pinch. OPEC's financial surpluses, which amounted to approximately $\$ 120$ billion in 1980 , were cut in half in 1981 and may be turned into a deficit in 1982. Countries such as Nigeria and Venezuela are already finding their development plans compromised. Yet energy remains a major international issue, and it is not in our best interests to abandon one-fifth of world trade to the hazards of successive reversals of trends.

In purely economic terms, the danger is already great. To believe that oil will behave like any other raw material is to forget that, in terms of lost production, the cost of oil shocks for the world economy bears no common measure with the cost of fluctuations in commodity prices ${ }^{6}$. To believe that market forces alone decide our energy future is to forget that the major investment effort needed to bring about the energy transition (3 percent of world GNP according to French expert Robert Lattes, that is, twice the present rate) requires a time frame not necessarily compatible with the short-term profitability of the oil companies. While the consumers rejoice, the exploration, substitution, and conservation policies that are a precondition for successful energy transition are now threatened by the confused signals given out by the market. Not only have most synfuel programs come to a halt (apparently on sound economic grounds but with worrisome implications for Western security), but oil exploration itself is clearly slowing down, thereby recreating the potential basis for future reversals of the market. As noted by S. Fred Singer, "Paradoxically, if oil users really believe that oil prices will fall, they will not invest in oil

6. See for example Sylvia Ostri, "Energy and Growth: The Impact of the Second Oil Shock on Performances of the OECD Economy," in Gregory Flynn, ed., Economic Interests in the 1980s: Convergence or Divergence (Paris: The Atlantic Institute for International Affairs, 1982). 
substitutes; but if they do not make these investments, prices will not fall"'?

Moreover, this policy appears even more risky when viewed in its geopolitical context. The success of Iran in the Gulf war in May and June 1982 and the inability of the Begin government to move from Camp David to a global, lasting peace in the Arab-Israeli conflict underline the persisting instability of the major oil-exporting region. Incidentally, the victory of the PasdaranIslamic militia-over one of the best armies of the region despite Iran's chaotic situation, is a reminder, like the fall of the Shah, of the fallibility of Western "expert" analysis. Assessments of the energy situation based on economic considerations alone are similarly vulnerable to abrupt rebuttal. The rise of Islamic fundamentalism in the fire belt stretching from the Western Sahara to Baluchistan seems particularly disquieting, signaling as it does the continuing shake-up of the cultural order (Western or Marxist) that provided a basis for internationalization of the economy. The combination of serious disturbances in Saudi Arabia and sudden stockpiling by the oil companies could alter, even in the medium term, a supply/demand equation that has already produced numerous surprises.

\section{Monetary disorder and the mounting tide of protectionism}

Islamic fundamentalism preached from the city of Qom is not the only threat to the shared values and objectives that make the growth of economic interdependence possible. The "monetarist fundamentalism" preached in the holy city of Chicago by Milton Friedman and religiously practiced by some devoute followers is also exacting its toll.

The foreign exchange markets are again subject to excessively large swings of the pendulum. Contrary to the hopes of their chief advocates, these fluctuations have been a corollary to the system of floating exchange rates. The rather inconclusive results of an economic policy that the Reagan administration invokes to exclude coordinated intervention by the Central Banks cannot warrant this disastrous return to "benign neglect."

Technically, the U.S. administration is right to think that interventions on the market have little impact on market forces. International monetary stability calls for a broader set of coordinated policies. The relative stability achieved in 1979-80 shows, however, that such policies are not beyond our reach. Countries such as Great Britain, which restricted their attention to the monetary aggregates, have only gradually come to realize the importance of giving at least some attention to exchange rate considerations. A successful and very free market-oriented country like Germany has long since gone beyond a narrow and enervating emphasis on monetary aggregates.

To those who wonder why, aside from altruistic considerations for the fate of foreign economies, the United States should take any interest in stabilizing international monetary relations, $C$. Fred Bergsten points out that

the postwar record reveals that an overvalued dollar is by far the greatest single threat to a liberal trade policy in the United States. The strongest challenge to this policy-culminating in the near-passage of the protectionist Mills bill in 1970 and Burke-Hartke proposals in 1971-1972, which would have limited virtually all U.S. imports-occurred at a time when the aggregate unemployment rate was at its lowest level in 20 years. But the final phase of the Bretton Woods system has then produced a dollar overvalued by about $15 \%$.... By contrast, in 1974, notwithstanding the highest level of unemployment since the Great Depresssion, Congress passed the Trade Act, authorizing the extensive trade liberalization that took place in the Tokyo Round of Multilateral Trade Negotiations; the dollar was then in rough equilibrium. ${ }^{8}$
7. S. Fred Singer, “An End to OPEC?” Foreign Policy (Winter 1981-82).
8. C. Fred Bergsten, "The Cost of Reaganomics," Foreign Policy (Fall 1981). 
International trade today could do without these additional sources of tension. An increasing number of agreements, delicately termed "selflimitation" agreements, are being signed with the blessing of advocates for a liberal trade policy. At the same time, the negotiation of a new Multifibre Agreement (MFA) in late 1981 marked a strengthening, at France's instigation in particular, of protectionist trade barriers vis-à-vis the countries of the South. Hence the emerging importance for these countries of South-South trade to which we devote particular attention this year.

The "trade guerrilla," which until recently confined itself to declining sectors, is spreading to the automobile industry and advanced-technology sectors such as electronics. In this field, Japan's conquest of a large share of the U.S. market for the most advanced components $(40 \%$ of the market for dynamic $16 \mathrm{~K}$ RAM memories and $70 \%$ of the nascent market for $64 \mathrm{~K}$ RAMs) signals an intensification of the competition for technological and industrial leadership. 9

The potential for conflict is multiplied by the importance that domestic policies (government procurement, R\&D policies, regional policies) now play in shaping internationally competitive relationships. It is no coincidence that a country like France, which relies on centrally defined industrial policies to stay in the leading league for certain advanced technologies (as it certainly should from a security and a long-term economic point of view), has used the Versailles summit to push technology to the forefront of international concerns. Technology indeed holds the potential of either taking us out of the present recession or of exacerbating social and international tensions.

9. Michael Borrus, James Millstein, and John Zysman, International Competition in Advanced Industrial Sectors: Trade and Development in the Semi-Conductor Industry, a study prepared for the Joint Economic Committee of the U.S. Congress (Washington, D.C.: Government Printing Office, 1982).

\section{Development and international security}

Mounting economic insecurity takes on very different forms depending on the region concerned. In reviewing industrial projects underway or in the planning stage in the rich Gulf Emirates, we cannot help being struck by the problems they are encountering in laying the groundwork for a non-oilbased industry. The insecurity of the producer states is in fact far greater than that of the consumer states. Beyond energy interdependence, the central precondition for a safer and more stable consumer-producer relationship is the achievement of genuine development.

Another form of dependence, in this case on a South Africa committed to apartheid, overshadows the development of the countries of South Africa. Whether they be landlocked or highly dependent states such as Botswana, Lesotho, Swaziland, or Malawi, or states better armed to pursue the struggle for African dignity (Zimbabwe, Mozambique, Angola, etc.), the countries of Southern Africa are faced with a choice between vassalage to Pretoria and a more autonomous development effort within the framework of a new regional community (the SADCC). The difficulties involved in the latter choice are underlined by the uncertainties now surrounding the originally promising Zimbabwe democratic experiment. However, by supporting these efforts for greater independence at the economic, ideological, and strategic levels, the Western world will contribute to the security of the region and, indirectly, to its own security.

At the same time, China is struggling to readjust its economy. This means reintroducing economic rationality and rebuilding the basic physical infrastructure, prerequisites for a genuine development that had been sacrificed under the voluntarist leadership of both Mao Zedong and Hua Guofeng. Insecurity in this case lies first and foremost in the fragility of Deng Xiaoping's domestic political situation. Yet the Western community can play a role in helping 
China to reenter the world economy, notably by enlarging China's access to the financial and technical resources of the development banks. This objective, of obvious strategic importance, again raises the broader subject of strengthening the international financial organization.

\section{Rebuilding world economic security}

Beyond the crowded agenda of immediate, national economic difficulties, as our report attempts to make clear, a more fundamental effort at restoring international security is urgently needed. There will be no lasting solutions to economic insecurity within every country if the present erosion of the international framework is left unchecked.

It would undoubtedly be an exaggeration to say that such considerations are at present completely overlooked. The Bank for International Settlements currently sponsors talks regarding the security of the international financial markets. Within the European monetary system, member countries are cooperating to ensure their monetary security in the face of the shockwaves of Reaganomics. The Paris conference on the least developed countries was concerned with strengthening the international "safety net" for the weakest nations. The IEA and EEC plead the cause of oil stockpoling policies. A ministerial conference within the framework of the GATT is planned for November 1982. However, the analysis presented here of each of these efforts shows that very few are pursued with the requisite vigor or within the global framework required. For example, the oil stockpiling policies adopted by the consumer countries are a step in the right direction but reflect a unilateral and partial view of energy security.

One searches in vain among this assortment of projects for a valid international strategy to face the crisis, a strategy eagerly awaited by a Western world in which unemployment stands at more than 30 million (more than the entire working population in France) and by a third world where 1 billion people live in absolute poverty. Yet it could be argued that international forums have been resounding for close to ten years with animated discussions on reforming the world economy. If the progress of these discussions could be accelerated, as twenty-one heads of state attempted at Cancun in October 1981 , would they not gradually result in the elaboration of new agreements and the establishment of new institutions by an interdependent world?

The majestic edifice of the New International Economic Order has the great merit to symbolize the third world's new awareness of its role and shared interests. Yet it has gradually become rigid, absorbing an energy which should be channeled into more concrete endeavours to tackle the present economic situation. The renegotiation of the Multifibre Agreement, for example, would have deserved receiving from the Southern countries some of the political priority which they concentrate on the United Nations forum.

Of course, our intention is not to draw in detail the outline of an alternative plan that might serve as a bridge between remote visions of the future and the constraints that are every day more paralyzing. Nevertheless, in examining field after field and region after region, it would seem that world economic security might provide the impetus for a renewed and revitalized dialogue.

Accordingly, we will roughly sketch the outline of a realistic dialogue between oil-producer and consumer countries. "Realistic" here implies that security is based on a balance of interests and of power, and not merely on presumed purity of intentions. In suggesting price-stabilization measures and a concerted international stockpiling policy, we will no doubt disappoint both the producers, who condemn any effort by the consumers to reduce their vulnerability, and those who currently rejoice in the present OPEC setbacks without measuring the dangers that fluctuating prices represent for energy tran- 
sition and their own long-term security. Yet each of these groups has in turn paid dearly for its policy of relying on the short-term balance of power.

The security of the non-oil-exporting developing countries warrants steppedup action on the part of the multilateral organizations (the World bank's "energy affiliate") for the development of energy resources, even though such resources might be of purely local interest. From this viewpoint, the San Jose de Costa Rica Agreement signed in August 1980 by Mexico, Venezuela, and the Caribbean countries appears to trace a path worth exploring more fully.

In the field of trade, the plan for new multilateral negotiations-concerning services in particular-appears unlikely in itself to offset the protectionist trend. More than ever the monetary dimension of the shifting competitive balance must be taken into account. Industrial cooperation and mutual acquaintance with one another's cultures should enrich Europe's relations with Japan; otherwise, trade disputes are likely to blind us to the geopolitical importance of the economic and strategic integration of this key country into the Western bloc. Combatting protectionist practices will also require a concerted stance by the major industrial democracies on social issues, employment, and the importance of a cooperative effort, thereby giving special attention to the third world countries, in order to share more equitably the benefits of new technologies.

It is well known that financial security is overshadowed by "country risks," but in addition it is threatened by what we refer to as system risks. The latter concern the distortions in the implementation of national monetary policies caused by the particular development of international liquidities. These distortions might one day lead the United States, whose role is far more decisive than that of the OPEC surplus countries, to restrict the supply of dollars to the eurosystem. Ideally, the required control mechanism would be a "variable geometry," allowing the system to retain its flexibility in periods of financial pressure while at the same time mod- erating speculative fever in times of monetary instability. We must overcome the awe that the mere mention of these unregulated markets evokes in many European quarters and the limitless fascination aroused in others by their remarkable resilience and capacity for adaptation.

Country risks, for their part, are due less to the absolute level of third world debt ( $\$ 520$ billion in 1981) than to its concentration in a small number of countries. Development, a very longterm process, is now financed on a short- or medium-term basis. In reality, this does not guarantee the security of the lenders (who are obliged to roll over their loans to avoid compromising their repayment) and at the same time renders the borrowers vulnerable to shortterm fluctuations exacerbated by U.S. interest rates. Clearly, the effectiveness of mechanisms such as the Club de Paris and the assistance of consultant banks have made it possible to confront many situations that would be termed "bankruptcies," were it not for a linguistic convention. But one may wonder whether the time has not come to move from constant "debt rescheduling" to a more thorough restructuring that would restore long-term financial instruments to their rightful place.

The most disquieting trend in our view, however, is the fragmentation of a financial market to which many countries have no access. This exclusion is especially hard on the African nations and will intensify as OPEC countries, now encountering difficulties, withdraw their funds. On purely economic criteria, certain "threshold countries" deserve greater access to the market, but they are penalized by the growing timidity of banks that have had their fingers burned in Brazil or Mexico. Hence the interest of the proposal presently under study for a partial guarantee of loans to such threshold countries.

For the poorest countries, however, aid will remain the best means of promoting the development of human resources and basic infractructures. Hence we assign great importance this year to an analysis of the crisis exploding in the 
World Bank and the International Development Association. The questioning of the role of multilateral aid calls for a more resolute attitude by the Europeans in international organizations. It also should lead to innovative formulas. For example, why not promote direct aid from the general and nongovernmental organizations by allowing gifts and loans on easy terms to benefit from the tax exemptions now reserved for other types of investment?

Our collective failure to account for the specifically international dimension of the present crisis is the major factor of insecurity. The occasional respites two years ago in the monetary field and today in the field of oil have often merely added to the disorder. Every opportunity should now be seized to propose ways of controlling the international risk.

The launching of global negotiations at the United Nations might afford one such opportunity, provided that the participants have the courage to set the agenda not according to the symbolic weight attached to the issues, but in the light of their relative relevance for world security. Likewise, Western economic summits have a key role to play, pro- vided they pursue the path traced at Tokyo toward genuine collective commitment. These summits might be followed up with meetings modeled after Cancun extended to third world countries whose influence is increasing in world affairs. In the longer term, the door should also be left open for including the Eastern countries, on the basis of the balance of power, in this multiform process of cooperation for security.

However, this procedure will only be valid if it helps lend shape and effectiveness to a collective desire, which has been quite inconspicuous these last few years, to strengthen the international foundations on which to build prosperity and development. Let us not give way to fear or helpless awe in the face of the profound complexity of interdependence. We should refuse to succumb to the belief expressed by the romantic poet Novalis, 10 that "this adaptation, transformation, dissolution of the divine and the human into uncontrollable forces is the spirit of the awful, devouring power that is nature."

\section{Albert Bressand June 17, 1982}

10. Novalis (Friedrich Freiherr von Hardenberg), The Novices of Sais, translated by Ralph Manheim and illustrated by Paul Klee (New York: Curt Valentin, 1949). 